\title{
The Development of Educational Leadership and Teaching Professions in Germany
}

\section{Pierre Tulowitzki}

University of Teacher Education Zug (PH Zug) - IBB Institute for the Management and Economics of Education (Switzerland)

doi: 10.7358/ecps-2015-011-tulo

pierre.tulowitzki@phzg.ch

\section{LO SVILUPPO DELLA LEADERSHIP EDUCATIVA \\ E LE PROFESSIONI DI INSEGNAMENTO IN GERMANIA}

\section{Abstract}

Teachers and school leaders are agents in a complex, ever-evolving system. Over time, there has been a shift towards team-orientation, the professionalization of teachership and leadership. This article presents a brief overview of several aspects of the German education system. First, the system itself is briefly introduced, including an introduction to the autonomy of the German federal states with regard to matters of education. This is followed by a short presentation of school leadership in Germany and how the role of school leaders has evolved over time. Next, teachership and the evolution of the teaching profession in Germany are briefly characterized. This also includes a brief section on standards for teacher training. Next, aspects of the professional development of teachers and school leaders are presented through the findings of several studies, chiefly the TALIS survey. Finally, challenges with regard to the professional development of teachers and school leaders in Germany are discussed.

Keywords: Development, Education system, Germany, Leadership, School improvement. 


\section{INTRODUCTION}

This article presents a brief overview of several aspects of the German education system. First, the system itself is introduced very briefly, followed by a short introduction of educational leadership and teaching in Germany. Next, aspects of the development are presented through the findings of several studies. Finally, challenges with regard to the professional development of teachers and school leaders in Germany are presented.

\section{THE GERMAN SCHOOL SYSTEM: A BRIEF OVERVIEW}

The German education system is deeply characterized by the federal autonomy: the 16 German states, called the "Bundesländer» (often abbreviated "Länder»), have the authority to make their own educational policies. This is linked to the so called «Kulturhoheit der Länder» («sovereignty of the states regarding cultural matters») which is part of the German "Grundgesetz», the basic law or constitution of Germany. It is, therefore, of no surprise that there is considerable variation between the individual states, making for a very complex education system overall (Neumann, Fischer, \& Kauertz, 2010; Eurydice Network, 2013). Compared to other European countries, a great deal of decision making power lies with the states, also referred to as «Länder» (see Table 1).

Table 1. - Percentage of decisions relating to public sector lower secondary education taken at each level of government. Source: OECD, 2012, p. 512.

\begin{tabular}{|c|c|c|c|c|c|c|c|}
\hline & Central & $S_{\text {TATE }}$ & $\begin{array}{c}\text { Provincial/ } \\
\text { Regional }\end{array}$ & $\begin{array}{c}\text { SUB- } \\
\text { REGIONAL }\end{array}$ & LOCAL & SCHOOL & TOTAL \\
\hline France & 32 & & 16 & 20 & & 32 & 100 \\
\hline Germany & & 36 & 13 & 8 & 21 & 23 & 100 \\
\hline Italy & 38 & & 19 & & 4 & 38 & 100 \\
\hline Portugal & 78 & & 8 & & & 22 & 100 \\
\hline Spain & 16 & 43 & 16 & & & 25 & 100 \\
\hline Switzerland & & 63 & & & 12 & 25 & 100 \\
\hline
\end{tabular}


There is, however, one unifying government body, the Kultusministerkonferenz (conference of ministers of Culture/Education, usually abbreviated $\mathrm{KMK})$. In this standing conference, the ministers of education of all 16 states regularly convene to discuss matters of education and to pass recommendations (Döbert, 2007). These recommendations are non-binding, but if all 16 states agree on something, then there is a good chance that this might be translated into a nationwide binding rule, usually taking the form of an overarching state treaty. For example, there are standards for high school graduation exams (the "Abitur») that are valid all over Germany that were passed based on recommendations and declarations of the KMK. The same is true for the "Bildungsstandards", nationwide academic standards for several subjects that shape the curricula and are competence-oriented (Hameyer \& Tulowitzki, 2013).

School is mandatory for children at the age of 6 , depending on the exact date of their birthday, sometimes also at the age of 7 (Secretariat of the Standing Conference of the Ministers of Education, 2013, p. 103 f.). Primary education lasts four years in most states, followed by a secondary education at one of several school types, the most common being the Realschule, which lasts until grade 10, or the Gymnasium, which lasts until grade 12 or 13 (depending on the state). In many states, children are required to attend school for a total of at least nine years. There is no homeschooling in Germany.

\section{SCHOOL LEADERSHIP IN GERMANY: A BRIEF OVERVIEW}

School principals in Germany are usually (experienced) teachers. They apply for school principal or deputy principal positions and are usually vetted and appointed by the Ministry of Education in charge. Applicants are usually expected to have some sort of management experience or qualification, be it through their job (i.e. having taken over special duties during their time as teachers at schools) or through further training. With respect to further training, there are a number of universities that offer masters programs for aspiring school principals. These programs are usually designed to prepare teachers for school leadership positions. However school principals are encouraged to participate as well. As there is no formal requirement for school principals to have a masters degree in school management or any other formal management training, a certain number of school principals lack thorough knowledge specifically revolving around school leadership.

School principals only have a limited dedicated administrative staff to support them, usually one secretary. They are often viewed as primus inter 
pares rather than separate entities. This is highlighted by the fact that school principals usually have a teaching obligation in Germany. In other words, they are part-time teachers and part time school leaders. While school leaders do play a key role in shaping the pedagogical profile and vision of a school, this role is counter-balanced by the pedagogical freedom of teachers, although in many states this pedagogical freedom is limited by the principal's authority. As many teachers are civil servants who can only be dismissed in cases of significant misconduct and as school principals do not have the authority to freely hire and dismiss staff (OECD, 2008, p. 55), the school principal's authority regarding matters of human resources can again be characterized as limited. Their autonomy with regard to determining course contents (one aspect of autonomy in curricular decision making) was found to be rather low when compared to other OECD countries (OECD, 2008, p. 46).

Regarding the focus of the work of school leaders, there has been a shift from administration, i.e. making sure the school runs smoothly, towards leadership, i.e. making sure the school (continues to) evolve(s). This shift occurred together with the spread of the school effectiveness and school improvement paradigms. Over time, expectations towards school principals to not only manage schools, but develop them (in conjunction with the staff) have arisen. This may be one of the reasons why the job of school principals in Germany is considered to be quite complex nowadays (Huber, 2008).

School principals are usually assisted by a deputy principal with similar duties. Additionally, schools have the possibility to have an «extended leadership team", a sort of steering committee with limited authority which is made up of teachers, the school principal and deputy principal.

While research has been advocating shared and distributed leadership structures for quite a while, there is no indication that this has had an impact on the way schools are led so far. Forms of truly shared leadership are rarely found in schools when looking at the principals and deputy principals.

\section{TEACHERS IN GERMANY: A BRIEF OVERVIEW}

Teachers in Germany usually have to complete masters-level studies before being able to become fully certified teachers. While the study program varies, aspects of leadership do not as yet play a significant role in the studies and training of aspiring teachers.

Similar to the profession of the school principals, the teaching profession has evolved considerably over the last 40 years. During the 1980 s teachers could be considered solitary transmitters of static knowledge, meaning 
that not much time and effort was invested in updating knowledge once the initial teacher training was completed. Also, there was not much emphasis on the cooperation of teachers. During the 1990s and 2000s, both of these aspects changed. Teachers became more and more encouraged to work in groups and support each other in and around the classroom. Additionally, the concept of lifelong learning (Fischer, 2000) took hold in the educational realm. The belief that people, in this case teachers, needed to continually keep their professional knowledge up-to-date, gained traction and became more and more widespread. As a consequence, the teaching profession is moving towards teachers being team-oriented learning-counselors with dynamic knowledge and further training being staples of the profession.

In 2004, the KMK passed standards for teacher training with regard to educational practices that have been adopted by all universities that offer teacher training and that shape the profile of teachers. These standards explicitly refer to and thus emphasize a declaration regarding the professional identity of teachers that was made jointly by the KMK and the head of the German Civil Servant Federation in 2000. In this declaration some key features of teachers are described (KMK, 2005, p. 3; translation by the author):

1. Teachers are experts for learning and teaching.

2. Teachers are mindful that education in school is linked to classroom instruction but also to school life.

3. Teachers evaluate and counsel in a competent, fair and responsible manner.

4. Teachers constantly develop their competencies.

5. Teachers participate in school improvement.

\section{THE PROFESSIONAL DEVELOPMENT OF TEACHERS}

The «Länder» are responsible for professional development. Professional development is mandatory for teachers and supervision of this is the responsibility of the school principal. All courses, workshops etc. have to be validated by the "Länder» beforehand to officially count as professional development.

In-service teacher training is foremost the responsibility of the "Länder», however, and the school principals are in charge of supervision. There are many state-run institutions that offer in-service training in addition to some cultural organizations, churches and universities. The latter three, however, have to be recognized by the "Land" in charge in order to be able to offer in-service teacher training courses. In-service teacher training usually serves to update and expand the teacher's knowledge in existing parts of his/her job (for example, learn about new methods or curricula in the subjects he/she teaches). 
Additionally, there is further training for teachers. While there is no formal definition separating in-service teacher training and further training, the latter is usually more expansive and takes a longer time to complete. Through measures of further training, teachers usually expand their knowledge into areas outside their current job profile. For example, they might get qualified and certified to teach another subject or to work as a counseling teacher (Secretariat of the Standing Conference of the Ministers of Education, 2013, p. 205).

\section{ProfESSIONAL DEVELOPMENT: TALIS}

In order to describe aspects of the professional development of teachers, data from TALIS (Teaching and Learning International Survey) is presented here. TALIS is an international survey focused on the working conditions of teachers and the learning environment in lower secondary schools. It uses self-report questionnaires and representative samples of schools and teachers within schools along with their principal (Vieluf, Kaplan, Klieme, \& Bayer, 2012, p. 13). It is a collaborative endeavor between the OECD, the governments of participating countries and teachers' unions. As the KMK decided that Germany should not participate in the TALIS study, there is no official TALIS data available. However, one of the major teacher unions in Germany subsequently decided to conduct the TALIS study on its own (with permission from the OECD). This introduced a possible bias into the study as only members of the major teacher union participated in the German TALIS study. Some results of the study are reported here.

With regard to professional development, virtually all participants indicated that they take part in professional development courses (Institut für Sozialwissenschaftliche Studien [ISS] e.V. \& Gewerkschaft Erziehung und Wissenschaft, 2009 , p. 9). More than $50 \%$ indicated that they had to pay a part or all of the costs of the professional development training, but this did not seem to have a great impact on their willingness to participate (ibid., p. 10). The two biggest reasons given for not participating in professional development courses were that there were no adequate courses available and that there were scheduling conflicts due to the development courses clashing with teaching obligations. Teachers also reported having wanted more professional development than they had received during the survey period, especially regarding teaching students with special learning requirements and regarding dealing with discipline and behavior problems (Vieluf et al., 2012, p. 11). 


\section{Challenges}

On its path to (further) professionalization, the German teacher education system faces a couple of challenges or issues. For teachers and school principals alike, the issue of physical and mental health has become more prominent in recent years. A study on teacher health in 2005 revealed that many teachers are at risk of having or developing health problems due to workrelated stress and the way they cope with it (Kieschke \& Schaarschmidt, 2008). Spurred by this study, the issues of teacher stress and teacher health have received renewed attention. Concurrently, greater emphasis has been placed on teachers' collaboration during pre-service and in-service teacher training. Collaborative structures are believed by many to be one way to help teachers cope with work-related stress (Friend \& Cook, 1990; Scheerens, 1990; for a more critical assessment, see Kelchtermans, 2006).

One criticism echoed predominantly by young teachers is that the first phase of teacher training, the Bachelor- and Master-studies taking place at a university or teacher university, is too theoretical and of limited relevance for the actual practice of being a teacher (Schultz, 2007). Over the last decades, universities have therefore (slowly) expanded the amount that students spend in school during their university studies, usually through hands-on training in schools, i.e. sending students to observe and work in schools for anywhere between several weeks and an entire semester.

Another issue often raised by young teachers is that during the second phase of teacher education, the practical period of teacher training (called "Referendariat»), the quality of the courses accompanying the practical phase varies. These courses are usually not provided by universities but by state institutes for teacher training. The state institutes typically employ teachers, preferably seasoned ones, to give courses to junior teachers. However, the selection process is far less rigorous than the selection process for becoming a university professor, for example.

In addition, an issue raised by teachers is the divide between what is taught during the first and second phase of teacher training and what is practiced later on (Knoke, 2013). For example, teachers in training are often required or encouraged to create detailed timetables of classes they have to teach, planning out the proposed class down to the minute. Deviations from these timetables during the actual classes (for example, to deal with an unforeseen occurrence) need to be justified and are often questioned by supervisors of teachers in training.

Furthermore, matters of leadership only play a role with regard to teacher leadership during teacher training. At first glance, this seems logi$\mathrm{cal}$ and adequate. However, school principals are recruited among teaching 
staff (teachers apply for principalship positions). (Optional) Courses covering aspects of leadership during the first and second phase of teacher training might therefore be a useful instrument to give teachers an idea what school leadership is all about. As a side effect, it might also be a way to raise interest in becoming a school principal as there are not enough school principals in Germany, particularly in primary schools (Breyer, 2014).

A current issue for school leaders in Germany is their professional status. Related to the increased relevance of school effectiveness and improvement paradigms, expectations towards school principals have shifted away from them being seen as teachers who manage the schools towards them being considered as dedicated managers and leaders. Principalship has been acknowledged as its own profession, separate from teachership (Buchen \& Rolff, 2013). Research indicates, however, that changes in educational governance need not necessarily lead to (corresponding) changes in leadership styles (Brauckmann \& Schwarz, 2014). At the same time, there is still no thorough, systematic pre-principal training in place, especially when compared to other countries (see Easley \& Tulowitzki, 2013). Regarding the professional development of school leaders, there is already a discernible trend towards a more dedicated qualification and certification process. More and more universities and academic institutions are offering courses of school administration, school management and the like. Similarly, principals are still required to teach. While many principals in Germany appreciate teaching, this requirement blurs the job profile of the school principal: if $s /$ he is supposed to be a school leader first and foremost, the teaching requirement seems questionable. To give a comparative example: in the French education system, school leaders at the secondary school level do not teach (Tulowitzki, 2013). Furthermore, greater autonomy with regard to matters of human resources would seem appropriate. In sum, the current situation with regard to school principalship can be described as being leadership-and management-oriented with remnants of the past conceptions of principalship still lingering.

\section{CONCLUSION}

Teachers and school leaders are agents in a complex, ever-evolving system. Over time, there has been a shift towards team-orientation, the professionalization of teachership and leadership. While professional development for teachers overall seems to be an established functional system, the same cannot yet be said for the professional development of school leaders. Their possibilities of professional development are not as systematically established 
as those of teachers. However, above all looms the issue of staggering complexity resulting from the autonomy of the sixteen states. While this individuality can be grounds for innovation, it can also be a source of hindrance and sluggishness.

The author wishes to thank the participants and organizers of the Conference Educational leadership in Latin Europe for their insights as well as the European Policy Network on School Leadership for supporting the dialogue on educational leadership.

\section{REFERENCES}

Breyer, A. (2014). Grundschule: Schulleiter gesucht! Die Zeit, January 26. Retrieved from: http://www.zeit.de/2014/04/grundschule-schulleiter-mangel.

Brauckmann, S., \& Schwarz, A. (2014). Autonomous leadership and a centralised school system: An odd couple? Empirical insights from Cyprus. International Journal of Educational Management, 28(7), 823-841. doi: 10.1108/IJEM-082013-0124.

Buchen, H., \& Rolff, H.-G. (Hg.). (2013). Vorwort. In Professionswissen Schulleitung (3rd ed., pp. 1-2). Weinheim: Beltz.

Döbert, H. (2007). Germany. In W. Hörner, H. Döbert, B. von Kopp, \& W. Mitter (Eds.), The education systems of Europe (pp. 299-325). The Netherlands: Springer. Retrieved from: http://link.springer.com/chapter/10.1007/1-4020-4874-2_20.

Easley, J., \& Tulowitzki, P. (2013). Policy formation of intercultural and globally minded educational leadership preparation. International Journal of Educational Management, 27(7), 744-761. doi: 10.1108/IJEM-04-2012-0050.

Eurydice Network (2013). Germany. Eurypedia - European Encyclopedia on National Education Systems, 22 November. Retrieved (10/05/2014) from: https:// webgate.ec.europa.eu/fpfis/mwikis/eurydice/index.php?title=Germany:Over view\&oldid $=90931$.

Fischer, G. (2000). Lifelong learning: More than training. Journal of Interactive Learning Research, 11 (3), 265-294.

Friend, M., \& Cook, L. (1990). Collaboration as a predictor for success in school reform. Journal of Educational and Psychological Consultation, 1(1), 69-86.

Hameyer, U., \& Tulowitzki, P. (2013). Reflecting curriculum trends in Germany: A conceptual framework for analysis. In W. Kuiper \& J. Berkvens (Eds.), Balancing curriculum regulation and freedom across Europe (pp. 81-98). Enschede, The Netherlands: SLO.

Huber, S. G. (2008). Steuerungshandeln schulischer Führungskräfte aus Sicht der Schulleitungsforschung. In R. Langer (Hg.), Warum tun die das? Governance- 
analysen zum Steuerungshandeln in der Schulentwicklung (pp. 95-126). Wiesbaden: VS Verlag für Sozialwissenschaften.

Institut für Sozialwissenschaftliche Studien (ISS) e.V. \& Gewerkschaft Erziehung und Wissenschaft (2009). Wirksame Lehr- und Lernumgebungen schaffen - Erste Ergebnisse von TALIS-GEW (Deutschland). Frankfurt am Main. Retrieved from: http://www.gew.de/Binaries/Binary50253/3_GEW_First_ Results_deck.pdf.

Kelchtermans, G. (2006). Teacher collaboration and collegiality as workplace conditions. A review. Zeitschrift für Pädagogik, 52(2), 220-237.

Kieschke, U., \& Schaarschmidt, U. (2008). Professional commitment and health among teachers in Germany: A typological approach. Learning and Instruction, 18(5), 429-437. doi: 10.1016/j.learninstruc.2008.06.005.

KMK (2005). Standards für die Lehrerbildung: Bildungswissenschaften (verabschiedet 2004). Zeitschrift für Pädagogik, 51(2), 280-290.

Knoke, M. (2013). Wenn junge Lehrer auf die brutale Realität treffen. Die Welt, December 14. Retrieved from: http://www.welt.de/wirtschaft/karriere/ article122915783/Wenn-junge-Lehrer-auf-die-brutale-Realitaet-treffen.html.

Neumann, K., Fischer, H. E., \& Kauertz, A. (2010). From PISA to educational standards: The impact of large-scale assessments on science education in Germany. International Journal of Science and Mathematics Education, 8(3), 545-563. doi: 10.1007/s10763-010-9206-7.

OECD (2008). Improving school leadership, Vol. 1: Policy and practice. Paris: OECD.

OECD (2012). Education at a glance 2012: OECD indicators. Paris: OECD.

Scheerens, J. (1990). School effectiveness research and the development of process indicators of school functioning. School Effectiveness and School Improvement, 1(1), 61-80. doi: 10.1080/0924345900010106.

Schultz, T. (2007). Lehrerausbildung: Testkind fürs Lehramt-Studium. Süddeutsche Zeitung, June 18. Retrieved from: http://www.sueddeutsche.de/karriere/ lehrerausbildung-testkind-fuers-lehramt-studium-1.582906.

Secretariat of the Standing Conference of the Ministers of Education (Ed.). (2013). The education system in the Federal Republic of Germany 2011/2012: A description of the responsibilities, structures and developments in education policy for the exchange of information in Europe. Bonn: KMK. Retrieved from: http:// www.kmk.org/fileadmin/doc/Dokumentation/Bildungswesen_en_pdfs/ dossier_en_ebook.pdf.

Tulowitzki, P. (2013). Leadership and school improvement in France. Journal of Educational Administration, 51(6), 812-835. doi: 10.1108/JEA-03-2012-0026.

Vieluf, S., Kaplan, D., Klieme, E., \& Bayer, S. (2012). Teaching practices and pedagogical innovations: Evidence from TALIS. Paris: OECD. doi: 10.1787/9789264123540en. 


\section{RiassunTO}

Insegnanti e dirigenti scolastici agiscono in un sistema complesso e in continua evoluzione. Nel corso del tempo, si è assistito ad uno sviluppo orientato verso il lavoro in team e verso la professionalizzazione nella gestione dell'insegnamento e della dirigenza. Questo articolo presenta una breve panoramica di alcuni aspetti del sistema educativo tedesco. In primo luogo viene brevemente introdotto il sistema stesso e viene presentata anche una descrizione del regime di autonomia, proprio degli stati federali tedeschi, sulle questioni relative all'istruzione. Segue una breve presentazione delle caratteristiche della leadership scolastica in Germania e di come si è evoluto il ruolo dei dirigenti scolastici nel tempo. Inoltre sono sinteticamente delineati la gestione dell'insegnamento e l'evoluzione della professione docente in Germania. Questa sezione comprende anche una breve indicazione sulle norme concernenti la formazione degli insegnanti. Gli aspetti dello sviluppo professionale degli insegnanti e dei dirigenti scolastici sono illustrate attraverso $i$ risultati di diversi studi, con particolare riferimento all'indagine TALIS. Infine vengono discusse le sfide in materia di sviluppo professionale degli insegnanti e dei dirigenti scolastici in Germania.

Parole chiave: Germania, Leadership, Miglioramento della scuola, Sistema educativo, Sviluppo del sistema educativo. 